UDC 352.075:502.7 (477-924.52)

Mykola P. Rybak ${ }^{1}$, Director of Carpathian Biosphere Reserve, Honored Environmental Guard of Ukraine

ORCID: orcid.org/0000-0003-3737-2433e-mail: mykola.rakhiv@ gmail.com

Vitalina V. Lukianova ${ }^{2}, \mathrm{PhD}$, Associate professor of the Department of Ecology and Safety of Vital Functions

ORCID: orcid.org/0000-0001-8964-3560e-mail: vitalina_lk@i.ua

Victoriia O. Khrutba ${ }^{2}$, Doctor of Technical Sciences, the Head of the Department of Ecology and Safety of Vital Functions

ORCID: orcid.org/0000-0002-8121-2042e-mail: Viktoriia.Khrutba@gmail.com

Yevheniia S. Anpilova ${ }^{3}$, PhD, Senior Research Scientist, Department of Natural Resources ORCID: orcid.org/0000-0002-4107-0617 e-mail: anpilova@ukr.net

${ }^{1}$ Carpathian Biosphere Reserve, Rakhiv, Ukraine

${ }^{2}$ National Transport University, Kyiv, Ukraine

${ }^{3}$ Institute of Telecommunications and Global Information Space of the National Academy of Sciences of Ukraine, Kyiv, Ukraine

\title{
DEVELOPMENT OF MANAGEMENT MEASURES TO BRING THE TERRITORY OF CARPATHIAN BIOSPHERE RESERVE INTO ALIGNMENT WITH THE INTERNATIONAL REQUIREMENTS
}

\begin{abstract}
The modern ecological challenges of the territories with conservation status have impact not only at the national level, but also at the global. That is why the solution to address the administrative challenges of these territories located in our country and bringing them into alignment with the international requirements is becoming more relevant.

The purpose of the study is to develop measures aiming to create a transit zone of the Carpathian Biosphere Reserve in the context of the sustainable development.

Research materials and methods of the study. From the traditional general scientific methods used: analysis and synthesis; comparison and analogy; generalization and abstraction; project management (planning and implementation of measures aiming to create a transit zone of the Carpathian Biosphere Reserve).

The relevance of this work is quite high. The conservation business in Ukraine is developing and improving every year. The process of increasing the conservation territories is relevant not only in Ukraine but also beyond its borders. Unfortunately, the legal framework of our state in the field of conservation does not fully ensure the proper use, reproduction and protection of the biosphere territories with conservation status.

The Carpathian Biosphere Reserve is one of the largest environmental, scientific, environmental and educational centers of the Carpathian region. Since 1993 it has been part of the World Network of Biosphere Reserves of the MAB-UNESCO.

The article gives an example of bringing the territory of a biosphere reserve to the international requirements for biosphere reserves; the main directions of activity aimed at collaboration of the administration of the Carpathian Biosphere Reserve with local communities and recommendations to implement the measures to ensure the creation of a transit zone of the biosphere reserve in Ukraine.
\end{abstract}

(C) M.P. Rybak, V.V. Lukianova, V.O. Khrutba, Y.S. Anpilova, 2019 
Some issues remained unresolved and some were only partially resolved, that is why the issue of improving the existing legal framework remains very relevant, taking into account the international commitments of Ukraine in the field of the sustainable development of reservation areas.

Keywords: sustainable development; natural reservation fund; biosphere reserve; transit zone

\section{Formulation of the challenge}

In 1974, the UNESCO Task Force on Man and Biosphere (MAB) has developed the main concept of biosphere reserves. The Biosphere Reserve Network began operating in 1976 and, as of 2016, the UNESCO MAB network included 669 reserves in 120 countries. Thus, biosphere reserves are referred to international structures [1] that are created under the MAB program. They include both the nature conservation areas and significant transitional areas or transition areas. This part of the Biosphere Reserve has no special conservation status and is created with the aim of implementing the concept of sustainable development here. The Carpathian Biosphere Reserve (CBR) belongs to the so-called old biosphere reserves, created before the appearance of the Seville Strategy and Statutory Framework (Regulation) of the World Network of Biosphere Reserves MAB UNESCO. At the time of its creation in 1993, it was a classic territory with conservation status and had a cluster structure [2]. At that time, the structure of the CBR was fully in line with the main goals of the biosphere reserves of that time to preserve the standards of the pristine natural complexes and to monitor them. However, in Ukrainian law [3] there is a disagreement between international and national categories of nature reserve fund (NRF). The NRF category of Ukraine - "Biosphere Preserve" was first introduced in 1992 when it passed the relevant Law [3], which distinguished biosphere preserves as a separate category of NRF, that is, they were created in Ukraine by Decree of the President rather than by UNESCO.

The Biosphere Reserve is a protected area that operates in accordance with the Law of Ukraine "On the Nature Reserve Fund of Ukraine" and which has rather severe restrictions on the use of nature in its territory. Instead, Biosphere Reserves are international structures created within the framework of the UNESCO Human and Biosphere Program [4]. The Carpathian Biosphere Reserve serves both the Biosphere Reserve and the Biosphere Preserve. The difference between these structures is very fundamental. Therefore, the development of management measures aimed to bring the territorial structures of Ukraine's biosphere preserves into alignment with the international requirements is urgent. This is necessary, first of all, because biosphere preserves (reserves), in accordance with UNESCO program documents, can play a significant role in the implementation of the Sustainable Development Strategy "Ukraine 2020", which was approved by the Decree of the President of Ukraine on January 12, 2015.

\section{Analysis of recent research and publications}

The Carpathian Biosphere Reserve is one of the largest environmental, scientific, environmental and educational centers of the Carpathian region. There are numerous scientific laboratories in the CBR, a network of monitoring sites, phenological points, hydro- and meteo-posts which have been established. The reserve is a natural 
laboratory for many domestic and foreign research institutions. There is a network of ecological-educational, scientific-cognition routes and information centers, the only museum of mountains ecology and history of the Carpathian Mountains which operates in Ukraine, its own video studio, the all-Ukrainian ecological-popular magazine "Green Carpathians"[5] on its territory.

The Carpathian Biosphere Reserve was established in 1968 in the IvanoFrankivsk and Transcarpathian regions. Since 1993, the CBR has been part of the International Network of Biosphere Reserves of the MAB-UNESCO. Today it covers an area of 58,035.8 ha, of which 39,485.8 ha are in permanent use. Its territory consists of eight separate arrays (Fig. 1), which are located in the territories of Vynohradiv, Rakhiv, Tyachiv and Khust administrative districts of the Transcarpathian region. The Carpathian Biosphere Reserve is located within the altitudes of 180-2061 m. m. - from the Transcarpathian lowland to the alpine belt, and represents practically all vegetation and climatic zones that are characteristic of the southwestern mega-hills of the Ukrainian Carpathians.

At the end of 2013, the Carpathian Biosphere Reserve prepared and submitted a Periodic Review (Report) covering the activities of the Biosphere Reserve over a 10-year period. In June 2014, according to the expert review of the report, the International Coordination Board of the UNESCO Program for Human and Biosphere (MAB) adopted a decision regarding the CBR, which, in particular, concluded that the reserve did not fully meet the criteria set out in the Statute framework of the World Network of Biosphere Reserves. The discrepancy with the above criteria is the insufficient size of the transition (transit) zone, which is due to the cluster nature of the territorial structure, significant fragmentation of the territory and its low ecological integrity and connectivity [6]. To address the decision mentioned above, the administration of the reserve began intensive work on the formation of the transit territory of the Carpathian Biosphere Reserve [7] in spring 2016.

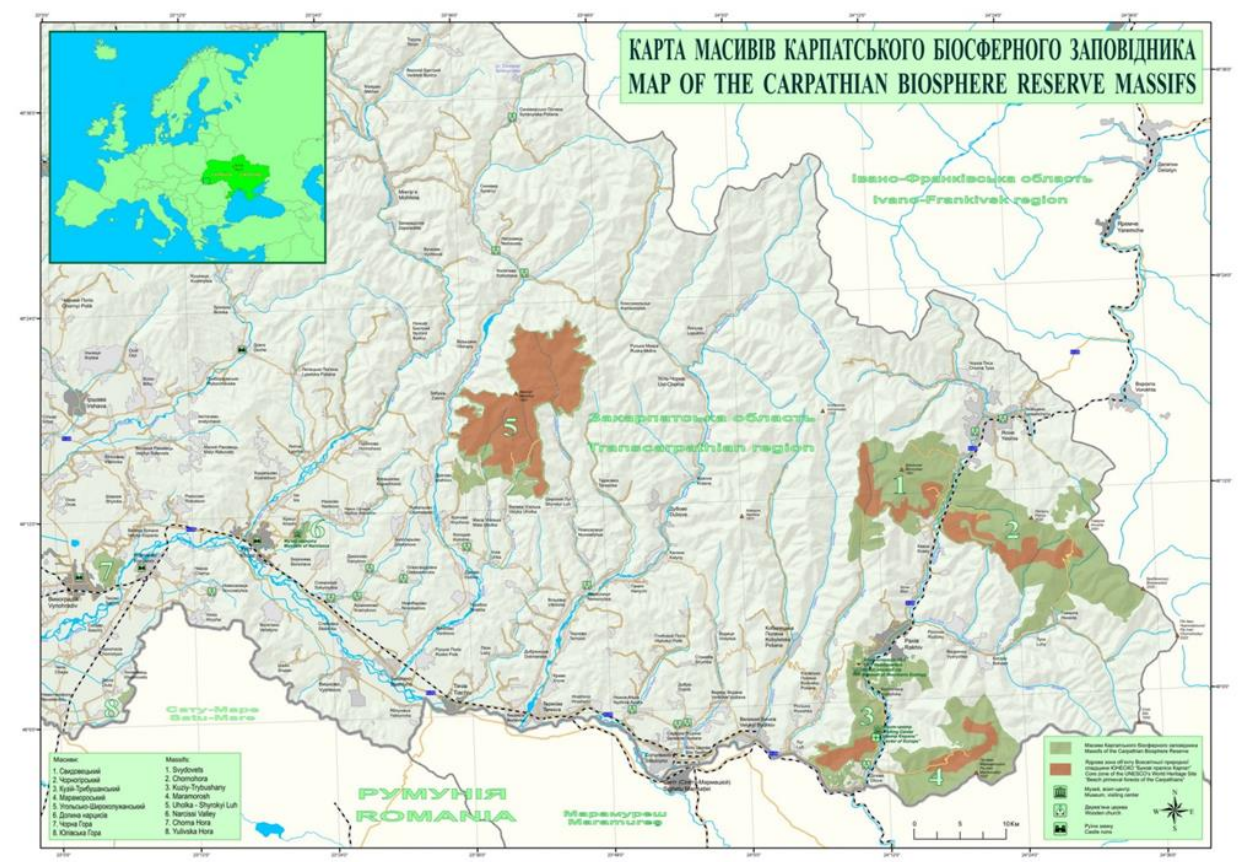

Figure 1 - Map of the Carpathian Biosphere Reserve arrays 
The purpose of the study is to develop measures aimed at creating a transit zone of the Carpathian Biosphere Reserve in the context of sustainable development.

To achieve this goal, the following tasks were adressed in this study:

- Analyze the main international requirements for biosphere reserves;

- Identify the main activities aimed at collaboration betweet the CBR's administration with the local communities;

- Develop recommendations for implementing measures to ensure the creation of a transit zone of the biosphere reserve in Ukraine.

\section{Research materials and methods}

From the traditional general scientific methods used: analysis and synthesis; comparison and analogy; generalization and abstraction; project management (planning and implementation of measures to create a transit zone of the Carpathian Biosphere Reserve).

\section{Results}

Biosphere Reserves (BRs) are land, coastal / marine territories, or a combination of these, which are recognized internationally under the UNESCO Human and Biosphere Program. Each BR must meet a set of criteria and a minimum number of conditions before being added to the Network. Each BR performs the following functions: conservation of genetic resources, species, ecosystems and landscapes; a function of development that will promote sustainable socio-economic development; and the logistics function to support demonstration projects, environmental education and training, as well as research and monitoring in the context of addressing local, national and global environmental and sustainable development issues. According to international requirements, BRs do not belong to nature conservation areas, because they do not belong to the categories of the International Union for Conservation of Nature, but are areas that are created to preserve biological diversity and ensure sustainable development and which should include the nature conservation area as an integral part. According to the Law of Ukraine [3], biosphere reserves have functional zoning, the central element of which is the protected territories.

In 1995, the UNESCO Conference adopted the Seville Strategy [8] and identified the main objectives for the development of biosphere reserves and the World Network of Biosphere Reserves as a whole:

Objective I. Use of Biosphere Reserves to Conserve Natural and Semi-Natural Diversity.

Task I.1. Improving conservation status of natural and semi-natural biodiversity through the Worldwide Network of Biosphere Reserves.

Task I.2. Integration of biosphere reserves into conservation planning.

Objective II. Using biosphere reserves as models of land management and approaches to sustainable development of regions

Task II.1. Providing support and involvement of the local population.

Task II.2. Provision of better harmonization and joint activity of subjects of different zones of biosphere reserves.

Task II.3. Integration of biosphere reserves into regional planning. 
Objective III. Use of biosphere reserves for research, monitoring, education and training

Task III.1. Improvement of knowledge about human-biosphere interaction.

Task III.2. Improvement of monitoring activities.

Task III.3. Improvement of education, community awareness and local involvement.

Task III.4. Training of specialists and managers.

Objective IV. Incarnation of the idea of a biosphere reserve.

Task IV.1. Integration of biosphere reserve functions.

Task IV.2. Strengthening the World Network of Biosphere Reserves.

According to the above, a conclusion is that BRs are special territories created in accordance with UNESCO provisions, where the conservation of biological and landscape diversity is closely aligned with the sustainable development of the territory. Management of the biosphere reserve should be carried out in accordance with the provisions of the UNESCO Seville Biosphere Reserve Development Strategy, the establishment of a coordination council and the development of a specific action plan.

To address it, a series of actions have been undertaken to bring the territory of the CBR into alignment with the international requirements.

The priority agreement was reached with the Transcarpathian Regional Directorate of Forestry and Hunting to establish a transit zone of the Carpathian Biosphere Reserve (CBR) in the territories of individual state forestry enterprises in order to ensure the sustainable management of the forest in the region. The creation of a transit zone or a sustainable development territory is documented by a special Memorandum of Cooperation and signed by the heads of both institutions on April 14, 2016.

According to this Memorandum, the CBR transit zone (Fig. 2) is formed by state forestry enterprises located directly within the area of activity of the Carpathian Biosphere Reserve within the Rakhiv and Tyachiv Administrative Regions of the Transcarpathian Region, namely "Rakhiv research forestry", "Yasinaske forestry" (Svidovetsky and Lopushansky forestries)," Velikobychekivka forestry" (except Verkhnyvodyansky forestry), " Brusturyansky forestry"(Hrunykivske forestry) and" Mokryanske forestry "(Tykhovetske, Krasnyanske, Ust-Chorna and Tarasovskaya foresties). Land plots of state forestry enterprises are included in the transit zone in order to introduce ideas of sustainable socio-economic development, in particular sustainable use of forest resources, increase their recreational attractiveness and to deepen cooperation in the conservation of valuable natural complexes. All of them, without exception, are certified under the international FSC scheme and meet all its criteria and principles.

The Memorandum also states that CBR administration and other forestry enterprises, as well as local communities located within the area of activity of the institution and nearby, should cooperate in the protection of natural and cultural complexes and objects for the socio-economic development of the Carpathian region. Priority areas for cooperation are: realization of the concept of sustainable use of forest resources, development of infrastructure, activation of recreational and tourism activities, reduction of environmental impact of economic activity, preparation of plans and programs for socio-economic development and implementation of relevant demonstration projects, search for funding and provision of appropriate resources, environmental education, training and skills development, 
public awareness and local involvement spare, common shares and so on. The CBR is of particular importance for the preservation of the culture of the Ukrainian Highlanders - Hutsuls, Boykiv and Lemkos. Some elements of the local environmental management, such as alpine dairy sheep, trout farms and related crafts and traditions, are unique to Ukraine and Europe.

In addition to the aforementioned Memorandum, the CBR administration has signed and signed Declarations of Cooperation between the CBR and a number of settlement and village councils to include them in the transit zone or the CBR sustainable development territory. As of October 30, 2017, such Declarations were signed with the territorial communities of the settlements of Bogdan, Luga, Vidrychka, Roztok, Cherna Tysa, Lazyshchina, Yasinya, Kvasy, Bilin, Kostylivka, Dilovo, Luh, Kosivska Polyana, and the cities of Rakhiv Rakhiv District and Coal, Wide Meadow and Big Coal of the Tyachiv district.

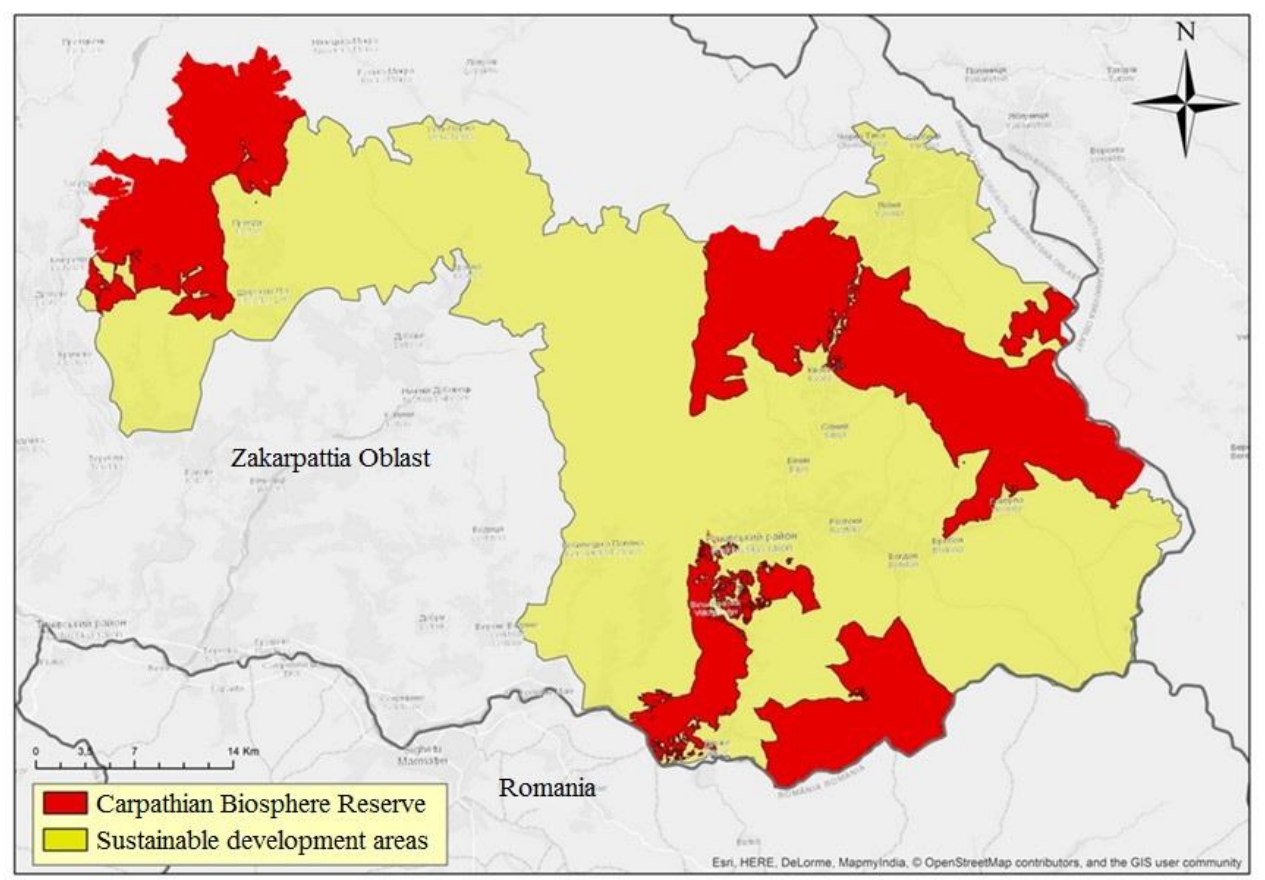

Figure 2 - Map diagram of the territory of the Carpathian Biosphere Reserve

The aforementioned state forestry enterprises and territorial communities form the territory of the transit zone with a total area of 124.3 thousand hectares. Thus, the total area of the reformed CBR territory is 181138.8 ha. The newly created CBR is a fragmented, holistic entity with high environmental connectivity and integrity, which provides, in particular, the viable populations of large carnivorous mammals: bear, wolf and lynx. It is important to note that the newly created territory of the transit zone includes a large part of the ecological network of the Transcarpathian region, including all the main latitudinal and meridional ecological corridors, which connect between them cluster sections of the biosphere reserve that have conservation status. All of these clusters have classical zoning, that is, include protected areas delimited by buffer zones from transit territory or the outer boundaries of the biosphere reserve. The CBR's new territorial structure and 
corresponding zoning will be reflected in the CBR Organization Project, which is essentially a ten-year management plan and is already underway. A map of the CBR territory with the newly created transit zone is added (Fig. 2).

\section{Conclusions}

Therefore, the administration of the CBR was able to solve one of the most relevant and important challengies in a short time by bringing its territorial structure and zoning accordingly to the requirements of the Statutory Framework criteria for the World Network of Biosphere Reserves, and thus maintaining the status of an institution of international importance in status of the Carpathian Biosphere Reserve.

\section{REFERENCES (TRANSLATED AND TRANSLITERATED)}

1. Categories, objectives and criteria for protected areas. (1978). Morges: IUCN.

2. Rybak, M. P., \& Proc, M. D. (2014). Sushasnij stan, problem ta shljaxi pokrashennja oxoroni teritorii Karpatskogo biosfernogo zapovednika. [Modern state, problems and ways of improvement of guard of territory of biosphere reserve of Carpathians]. In Osnovy upravlinnia biosfernymy rezervatamy $v$ Ukraini. Mizhnarodnyi naukovo-praktychnyi seminar «Rozvytok systemy biosfernykh rezervativ v Ukraini» (1-3 zhovtnia 2014 roku, Uzhanskyi natsionalnyi pryrodnyi park, Zakarpatska oblast) (pp. 258-261). Ujgorod: KP «Ujgorod city print». (in Ukrainian).

3. Zakon Ukraini «Pro prirodno-zapovidnij fond Ukraini». (1992). [Law of Ukraine «About the naturally protected fund of Ukraine»: on June, 16, 1992]. Kiev: Vidomosti Verhovnoi Radi Ukraini (in Ukrainian).

4. Didyx, Ja. P., Parchuk, G. V. (2014). Stan ta perspektivi rozvitku merezhi biosfernih rezervativ v Ukraïni [The state and prospects of development of network of biosphere резерватів are in Ukraine]. In Osnovy upravlinnia biosfernymy rezervatamy v Ukraini. Mizhnarodnyi naukovo-praktychnyi seminar «Rozvytok systemy biosfernykh rezervativ $v$ Ukraini» (1-3 zhovtnia 2014 roku, Uzhanskyi natsionalnyi pryrodnyi park, Zakarpatska oblast) (pp. 144-150). Ujgorod: KP «Ujgorod city print» (in Ukrainian).

5. Vidannja ta publikaciï Karpats'kogo biosfernogo zapovidnika [Edition and publications of biosphere reserve of Carpathians]. (n.d.). Retrieved January 18, 2019, from http://cbr.nature.org.ua/vydan_u.htm

6. Rekomendaciï mizhnarodnogo naukovo-praktichnogo seminaru «Rozvitok sistemi biosfernih rezervativ v Ukraïni». (2014). [Recommendations of international research and practice seminar are "Development of the system of biosphere резерватів in Ukraine"]. In Osnovy upravlinnia biosfernymy rezervatamy $v$ Ukraini. Mizhnarodnyi naukovopraktychnyi seminar «Rozvytok systemy biosfernykh rezervativ v Ukraini» (1-3 zhovtnia 2014 roku, Uzhanskyi natsionalnyi pryrodnyi park, Zakarpatska oblast). Ujgorod: KP «Ujgorod city print». (in Ukrainian).

7. Rybak, M. P. (2016). Pro privedennja teritorial'noï strukturi Karpats'kogo biosfernogo rezervatu (Ukraïna) u vidpovidnist' do kriteriïv Statutnih ramok (Polozhennja) Vsesvitn'oï merezhi biosfernih rezervativ MAB JuNESKO [About bringing of territorial structure of biosphere резервату of (Ukraine) Carpathians to conformity with the criteria of the Regulation scopes (Position) of the World network of biosphere резерватів of МАБ of UNESCO]. Green Carpathians, (1-4), 6-9. (in Ukrainian).

8. Sevilian strategy: aim and task. (n.d.). Retrieved January 18, 2019, from http://www.unesco.org/new/en/natural-sciences/environment/ecological-sciences/. 


\section{СПИСОК ЛІТЕРАТУРИ}

1. Categories, objectives and criteria for protected areas. - Morges: IUCN, 1978, 25 p.

2. Рибак М.П., Проць М.Д. Сучасний стан, проблеми та шляхи покращення охорони території Карпатського біосферного заповідника // Основи управління біосферними резерватами в Україні. Міжнародний науково-практичний семінар «Розвиток системи біосферних резерватів в Україні» (1-3 жовтня 2014 року, Ужанський національний природний парк, Закарпатська область). - Ужгород: КП «Ужгородська міська друкарня», 2014. - С. 258-261.

3. Про природно-заповідний фонд України: Закон України 16 червня 1992 року // Відомості Верховної Ради України. - 1992. - № 34. - С. 502.

4. Дідух Я.П., Парчук Г.В. Стан та перспективи розвитку мережі біосферних резерватів в Україні // Основи управління біосферними резерватами в Україні. Міжнародний науково-практичний семінар «Розвиток системи біосферних резерватів в Україні» (1-3 жовтня 2014 року, Ужанський національний природний парк, Закарпатська область). - Ужгород: КП «Ужгородська міська друкарня», 2014. - С. 144-150.

5. Видання та публікації Карпатського біосферного заповідника - Режим доступу: http://cbr.nature.org.ua/vydan_u.htm

6. Рекомендації міжнародного науково-практичного семінару «Розвиток системи біосферних резерватів в Україні» // Основи управління біосферними резерватами в Україні. Міжнародний науково-практичний семінар «Розвиток системи біосферних резерватів в Україні» (1-3 жовтня 2014 року, Ужанський національний природний парк, Закарпатська область). - Ужгород: КП «Ужгородська міська друкарня», 2014. C. 12-19.

7. Рибак М.П. Про приведення територіальної структури Карпатського біосферного резервату (Україна) у відповідність до критеріїв Статутних рамок (Положення) Всесвітньої мережі біосферних резерватів МАБ ЮНЕСКО // Зелені Карпати. - 2016. № 1-4. - C. 6-9.

8. Севільська стратегія: мета та завдання [Електронний ресурс]. - Режим доступу: http://www.unesco.org/new/en/natural-sciences/environment/ecological-sciences/

The article was received 03.10.2019 and was accepted after revision 01.11.2019

\section{М.П. Рибак, В.В. Лук'янова, В.О. Хрутьба, С.С. Анпілова \\ РОЗРОБКА УПРАВЛІНСЬКИХ ЗАХОДІВ ЩОДО ПРИВЕДЕННЯ ТЕРИТОРІЇ КАРПАТСЬКОГО БІОСФЕРНОГО ЗАПОВІДНИКА ДО МІЖНАРОДНИХ ВИМОГ}

Анотація. Сучасні екологічні проблеми заповідних територій мають не просто загальнодержавний, а й глобальний характер. А тому вирішення управлінських проблем цих територій нашої держави і приведення їх до міжнародних вимог стає дедалі актуальнішим.

Метою дослідження $є$ розробка заходів, спрямованих на створення транзитної зони Карпатського біосферного резервату в контексті сталого розвитку.

Матеріали та методи дослідження. 3 традиційних загальнонаукових методів застосовувалися: аналіз і синтез; порівняння та аналогія; узагальнення та абстрагування; управління проектами (планування і здійснення заходів щодо створення транзитної зони Карпатського біосферного резервату).

Актуальність даної роботи є досить високою. Заповідна справа на Україні розвивається та удосконалюється з кожним роком. Процес збільшення природнозаповідних територій актуальний не тільки в Україні, але і за іiі межами. На жаль, правова база нашої держави у сфері заповідної справи не повністю забезпечує належне використання, відтворення та охорону територій біосферних заповідників. 
Карпатський біосферний заповідник є одним з найбільших природоохоронних, наукових, еколого-освітніх центрів Карпатського регіону. Із 1993 року він входить до Міжнародної мережі біосферних резерватів МАБ-ЮНЕСКО.

У статті наведено приклад приведення території біосферного заповідника до міжнародних вимог, що висуваються до біосферних резерватів; визначено основні напрями діяльності, спрямовані на взаємодію адміністрації Карпатського біосферного заповідника із місцевими громадами та розроблено рекомендації щодо впровадження заходів забезпечення утворення транзитної зони біосферного резервату в Україні.

Окремі питання залишились неврегульованими, а деякі вирішені лише частково, тому вкрай актуальним залишається питання удосконалення існуючої нормативноправової бази з урахуванням відповідних міжнародних зобов'язань України у сфері подальшого розвитку заповідної справи.

Ключові слова: сталий розвиток; природно-заповідний фонд; біосферний резерват; транзитна зона

\section{Рибак Микола Петрович}

директор Карпатського біосферного заповідника, заслужений природоохоронець України

Адреса робоча: 90600, Україна, м. Рахів, вул. Красне Плесо, 77

e-mail: mykola.rakhiv@gmail.com

ORCID: orcid.org/0000-0003-3737-2433

\section{Лук'янова Віталіна Віталіївна}

кандидат хімічних наук, доцент кафедри екології та безпеки життєдіяльності Національного транспортного університету

Адреса робоча: 01010, Україна, м. Київ, вул. Омельяновича-Павленка 1, к. 312

e-mail: vitalina_lk@i.ua

ORCID: orcid.org/0000-0001-8964-3560

\section{Хрутьба Вікторія Олександрівна}

доктор технічних наук, завідувач кафедри екології та безпеки життєдіяльності Національного транспортного університету

Адреса робоча: 01010, Україна, м. Київ, вул. Омельяновича-Павленка 1, к. 312

e-mail: viktoriia.khrutba@gmail.com

ORCID: orcid.org/0000-0002-8121-2042

\section{Анпілова Свгенія Сергіївна}

кандидат технічних наук, старший науковий співробітник відділу природних ресурсів Інституту телекомунікацій і глобального інформаційного простору НАН України

Адреса робоча: 03186 Україна, м. Київ, Чоколівський бульвар, 13

e-mail: anpilova@ukr.net

ORCID: orcid.org/0000-0002-4107-0617 